\title{
Vanillin-Based Polymers-part II: Synthesis of Schiff Base Polymers of Divanillin and Their Chelation with Metal Ions
}

\author{
Ananda S. Amarasekara and Ashfaqur Razzaq \\ Department of Chemistry, Prairie View A\&M University, Prairie View, TX 77446, USA \\ Correspondence should be addressed to Ananda S. Amarasekara, asamarasekara@pvamu.edu \\ Received 5 September 2012; Accepted 27 September 2012 \\ Academic Editors: A. He and B. F. Senkal
}

Copyright ( $) 2012$ A. S. Amarasekara and A. Razzaq. This is an open access article distributed under the Creative Commons Attribution License, which permits unrestricted use, distribution, and reproduction in any medium, provided the original work is properly cited.

Condensation of renewable resources-based monomer divanillin with alkyl diamines gives Schiff base polymers with degree of polymerization (DP) 25-32 in 88-95\% yield. These yellow polymers are insoluble in water and common organic solvents, slightly soluble in warm DMSO, DMF and dissolves in aqueous $\mathrm{NaOH}$. The polymers were characterized using FT-IR, ${ }^{1} \mathrm{H}$, and ${ }^{13} \mathrm{C}$ NMR spectroscopy and by comparison with the model compound $N, N^{\prime}$-bis(vanillidene)-1,3-propanediamine. Polymer prepared by condensation of divanillin and 1,6-diaminohexane is shown to chelate with $\mathrm{Cu}(\mathrm{II}), \mathrm{Fe}(\mathrm{II})$, and $\mathrm{Co}$ (II) metal ions in basic aqueous methanol.

\section{Introduction}

Synthesis of polymeric and composite materials from renewable resources-based feedstock has attracted an increasing attention over the last two decades due to concerns over dwindling petroleum resources $[1,2]$. Some of the renewable resources-based monomers currently under study are triglycerides [3, 4], 1,3-propanediol [5], furfural [6, 7], 2,5furandicarboxylic acid or its derivatives [8-10], lactic acid [11], and levulinic acid [12, 13]. Vanillin (1, Figure 1) is another biomass-derived compound that can be considered as a potential renewable feedstock chemical. This phenolicaldehyde was first isolated from vanilla extract used as a common food flavoring, which is derived from orchids of the genus Vanilla, and primarily from the Mexican species, Vanilla planifolia. Recent advancements in the production of vanillin by metal catalyzed air oxidation of abundant lignin have promoted the status of this old world flavor chemical to another promising renewable feedstock material for the chemical and polymer industries [14-16]. Alternative biotechnology-based approaches applying fungi, bacteria, plant cells, and genetically engineered microorganisms are also currently under study [17] for the large scale production of this highly functionalized versatile building block. Even though the lignin derived vanillin is becoming relatively easily accessible, still there are only a handful of reports on attempts to utilize vanillin or vanillin derivatives as monomers for the renewable resources-based polymer synthesis. In one example, Gosling et al. have recently reported [18] the preparation of 3-carboxy muconate as a monomer by an enzymatic transformation of vanillin. Furthermore, as a proof of the principle, they demonstrated that trimethyl ester derivative of 3-carboxy muconate can be copolymerized with styrene to give novel polyesters. In another recent example, vanillin-derived dihydroferulic acid has been used in the preparation of a polyester [19]. In these experiments, vanillin was subjected to the Perkin reaction with acetic anhydride and then hydrogenation to afford acetyl dihydroferulic acid. Polymerization of this monomer produced poly(dihydroferulic acid), which exhibits thermal properties similar to those of polyethylene terephthalate (PET). Additionally, the related compound ortho-vanillin has been used in the synthesis of organometallic polymers as well, where a Schiff base polymer derived from ortho-vanillin has been shown to complex with various metal ions [20].

$6,6^{\prime}$-Dihydroxy-5, 5' - dimethoxy-( $1,1^{\prime}$ - biphenyl $)-3,3^{\prime}$ dicarboxaldehyde (2, Figure 1 ) or the compound commonly known as divanillin is the symmetrical dimer of vanillin and can be easily prepared from vanillin by $\mathrm{FeCl}_{3}$ [21] or enzyme catalyzed [22] oxidative dimerization. This symmetrical 


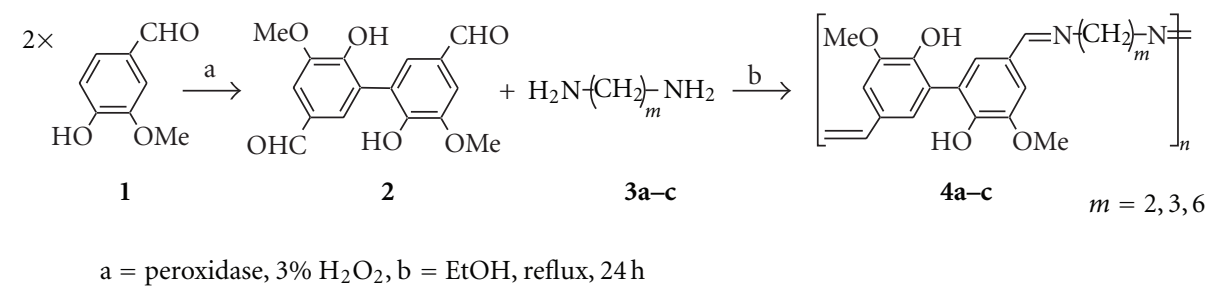

FIGURE 1: Synthesis of divanillin Schiff base polymers $(\mathbf{4 a - c})$.

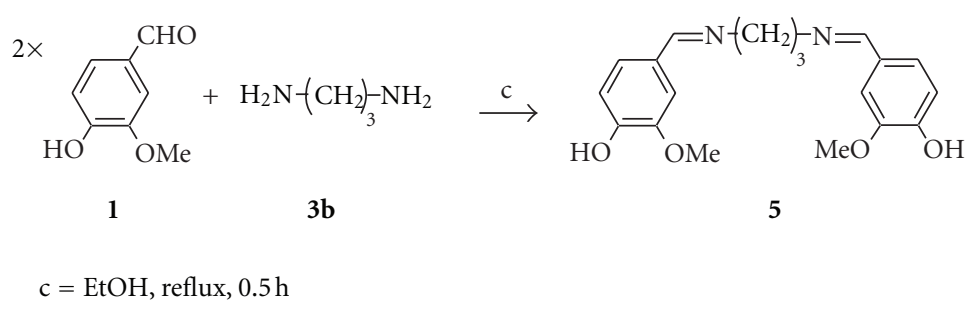

Figure 2: Synthesis of the model compound $N, N^{\prime}$-bis(vanillidene)-1,3-propanediamine (5).

dimer is a reactive polyfunctional molecule, hence, very attractive as a monomer, and we recently reported the preparation of polyvanillin using divanillin as the building block. In this experiment, divanillin was polymerized in aqueous sodium hydroxide at a lead cathode to produce polyvanillin in $91 \%$ yield [23]. As an extension of our interests in the use of renewable resources based monomers for the synthesis of novel polymeric materials $[13,23,24]$ and application of divanillin as a polymer precursor [23], we have studied the synthesis of divanillin Schiff base polymers, and their chelation properties with metal ions.

\section{Experimental}

2.1. Materials and Instrumentation. Vanillin, ethylenediamine, 1,3-propanediamine, 1,6-hexanediamine, 3\% hydrogen peroxide, peroxidase (from horseradish, 59 units $/ \mathrm{mg}$ ), $\mathrm{CuCl}_{2} \cdot 2 \mathrm{H}_{2} \mathrm{O}, \mathrm{FeCl}_{2} \cdot 4 \mathrm{H}_{2} \mathrm{O}$, and $\mathrm{CoCl}_{2} \cdot 6 \mathrm{H}_{2} \mathrm{O}$ were purchased from Aldrich Chemical Co. ${ }^{1} \mathrm{H}$ NMR Spectra were recorded in DMSO- $d_{6}$ on a Varian Mercury plus spectrometer operating at $400 \mathrm{MHz}$, and chemical shifts are given in ppm downfield from TMS $(\delta=0.00) .{ }^{13} \mathrm{C}$ Chemical shifts were measured relative to DMSO- $d_{6}$, using $\delta$ (DMSO) = 39.5. FT-IR spectra were recorded on a Thermo Nicolet IR 200 spectrometer using $\mathrm{KBr}$ pellets. Elemental analysis was performed at QTI laboratories, NJ, USA. Thermogravimetric analysis was carried out in air on a Perkin Elmer Diamond TG/DTA system in $25-800^{\circ} \mathrm{C}$ temperature range, $10^{\circ} \mathrm{C} / \mathrm{min}$, and using Pt crucibles.

2.2. Synthesis of Divanillin (2). Divanillin (2) was prepared by horseradish peroxidase catalyzed oxidative dimerization of vanillin (1) using 3\% hydrogen peroxide as the oxidant, as a gray powder in $95 \%$ yield, following the literature procedure [22].
IR (KBr) 744, 848, 1044, 1151, 1260, 1400, 1423, 1450, $1587,1675,3310 \mathrm{~cm}^{-1}$.

${ }^{1} \mathrm{H}$ NMR (DMSO- $\left.d_{6}\right) \delta 3.91\left(\mathrm{~s}, 6 \mathrm{H}, 2 \mathrm{X}-\mathrm{OCH}_{3}\right), 7.41$ (bs, $4 \mathrm{H}, \mathrm{Ar}), 9.78(\mathrm{~s}, 2 \mathrm{H}, \mathrm{CHO}), 9.95(\mathrm{bs}, 2 \mathrm{H}, \mathrm{OH}) ;{ }^{13} \mathrm{C} \mathrm{NMR}$ $\left(\mathrm{DMSO}-d_{6}\right) 56.5\left(\mathrm{OCH}_{3}\right), 109.6(\mathrm{Ar}), 124.9(\mathrm{Ar}), 128.1(\mathrm{Ar})$, 128.6(Ar), 148.6(Ar), 150.9(Ar), 191.7(CHO).

2.3. General Procedure for the Synthesis of Divanillin Schiff Base Polymers $(4 \mathrm{a}-\mathrm{c})$. A mixture of divanillin $(0.302 \mathrm{~g}$, $1.00 \mathrm{mmol})$, and diamine $3 \mathrm{a}-\mathrm{c}(1.00 \mathrm{mmol})$ in $60 \mathrm{~mL}$ of ethanol was heated under reflux for $24 \mathrm{~h}$. Then the reaction mixture was cooled, filtered, and washed with cold ethanol $(2 \mathrm{X} 10 \mathrm{~mL})$ to give divanillin Schiff base polymers $(\mathbf{4 a}-\mathbf{c})$ as yellow powders. Degree of polymerization (DP) of polymers was calculated by end-group analysis method, using ${ }^{1} \mathrm{H}$ NMR (DMSO- $d_{6}$ ) peak area ratios of $-\mathrm{HC}=\mathrm{N}-$ of polymer $(\sim 8.2 \mathrm{ppm})$ and unreacted-CHO end groups $(\sim 9.7 \mathrm{ppm})$.

4a: $88 \%$ yield. Anal. Calc. for $\left(\mathrm{C}_{18} \mathrm{H}_{18} \mathrm{~N}_{2} \mathrm{O}_{4}\right)_{n}$ : C, 66.25; H, 5.56; N, 8.58\%. Found: C, 66.61; H, 5.38; N, 8.39\%. DP = 25.

4b: $92 \%$ yield. Anal. Calc. for $\left(\mathrm{C}_{19} \mathrm{H}_{20} \mathrm{~N}_{2} \mathrm{O}_{4}\right)_{n}$ : C, 67.05; H, 5.92; N, 8.23\%. Found: C, 67.41; H, 5.88; N, 8.15\%. DP = 28.

4c: $95 \%$ yield. Anal. Calc. for $\left(\mathrm{C}_{22} \mathrm{H}_{266} \mathrm{~N}_{2} \mathrm{O}_{4}\right)_{n}$ : C, 69.09; H, 6.85; N, 7.35\%. Found: C, 69.31; H, 6.78; N, 7.15\%. DP = 32.

2.4. Synthesis of the Model Compound N,N'-bis(vanillidene)1,3-propanediamine (5). A mixture of vanillin (1.52 g, $10.0 \mathrm{mmol})$ and 1,3 -propanediamine $(0.37 \mathrm{~g}, 5.0 \mathrm{mmol})$ in $10 \mathrm{~mL}$ of ethanol was heated under reflux for $30 \mathrm{~min}$. Then the solution was cooled to room temperature and allowed to stand at room temperature overnight. Evaporation of the solvent gave $N, N^{\prime}$-bis(vanillidene)-1,3-propanediamine (5) as a yellow viscous oil, $1.60 \mathrm{~g}, 99 \%$ yield. 


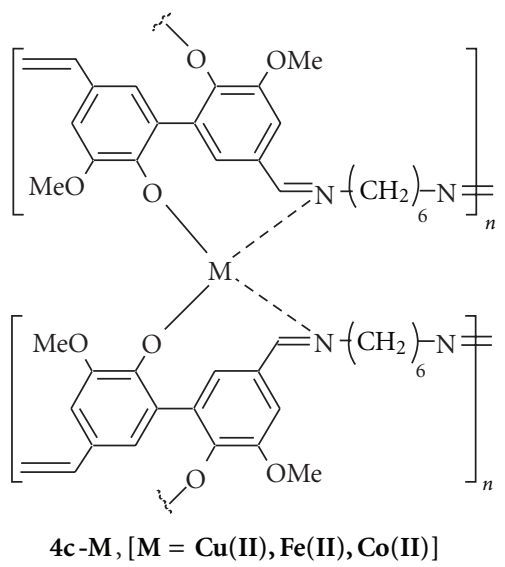

Figure 3: Proposed structure for metal complexes 4c-M [M= Cu(II), $\mathrm{Fe}(\mathrm{II}), \mathrm{Co}(\mathrm{II})]$.

Table 1: ${ }^{1} \mathrm{H}$ and ${ }^{13} \mathrm{C}$ NMR data of divanillin Schiff base polymers $(\mathbf{4 a}-\mathbf{c})$ in DMSO- $d_{6}$.

\begin{tabular}{lll}
\hline Polymer & ${ }^{1} \mathrm{H}(\mathrm{ppm})$ & ${ }^{13} \mathrm{C}(\mathrm{ppm})$ \\
\hline \multirow{2}{*}{ 4a } & $3.50(\mathrm{OH}), 3.64\left(2 \mathrm{XCH}_{2}\right), 3.75\left(\mathrm{OCH}_{3}\right), 7.28(\mathrm{Ar}), 7.48$ & $55.7\left(2 \mathrm{XCH}_{2}\right), 57.5\left(\mathrm{OCH}_{3}\right), 107.8(\mathrm{Ar}), 126.2(\mathrm{Ar}), 128.3(\mathrm{Ar}), 130.0$ \\
& $(\mathrm{Ar}), 8.14(\mathrm{CH}=\mathrm{N})$ & \\
& $2.03\left(\mathrm{CH}_{2}\right), 3.50(\mathrm{OH}), 3.58\left(2 \mathrm{XCH}_{2}\right), 3.75\left(\mathrm{OCH}_{3}\right)$, & $29.5\left(\mathrm{CH}_{2}\right), 56.7\left(2 \mathrm{XCH}_{2}\right), 58.3\left(\mathrm{OCH}_{3}\right), 107.2(\mathrm{Ar}), 126.1(\mathrm{Ar})$, \\
$4 \mathbf{b}$ & $7.28(\mathrm{Ar}), 7.48(\mathrm{Ar}), 8.15(\mathrm{CH}=\mathrm{N})$ & $128.3(\mathrm{Ar}), 130.0(\mathrm{Ar}), 151.6(2 \mathrm{XC}, \mathrm{Ar}), 164.5(\mathrm{CH}=\mathrm{N})$ \\
& $1.24\left(2 \mathrm{XCH}_{2}\right), 1.56\left(2 \mathrm{XCH}_{2}\right), 3.50(\mathrm{OH}), 3.52$ & $26.6\left(2 \mathrm{XCH}_{2}\right), 30.5\left(2 \mathrm{XCH}_{2}\right), 55.6\left(2 \mathrm{XCH}_{2}\right), 55.7\left(\mathrm{OCH}_{3}\right), 107.7$ \\
& $\left(2 \mathrm{XCH}_{2}\right), 3.75\left(\mathrm{OCH}_{3}\right), 7.15(\mathrm{Ar}), 7.38(\mathrm{Ar}), 8.20$ & $(\mathrm{Ar}), 128.1(\mathrm{Ar}), 128.6(\mathrm{Ar}), 129.8(\mathrm{Ar}), 151.0(\mathrm{Ar}), 151.5(\mathrm{Ar}) 162.0$ \\
$4 \mathbf{c}$ & $(\mathrm{CH}=\mathrm{N})$ & $(\mathrm{CH}=\mathrm{N})$ \\
& &
\end{tabular}

TABle 2: Decomposition onset temperature $\left(T_{\text {onset }}\right)$ and derivative thermogravimetric analysis (DTG) peaks data of divanillin Schiff base polymers $(\mathbf{4 a - c})$.

\begin{tabular}{lcc}
\hline Polymer & $T_{\text {onset }} /{ }^{\circ} \mathrm{C}$ & $\mathrm{DTG} /{ }^{\circ} \mathrm{C}$ \\
\hline $\mathbf{4 a}$ & 255 & 345,492 \\
$\mathbf{4 b}$ & 245 & 375,478 \\
$\mathbf{4 c}$ & 250 & 350,475 \\
\hline
\end{tabular}

Anal. Calc. for $\mathrm{C}_{19} \mathrm{H}_{22} \mathrm{~N}_{2} \mathrm{O}_{4}$ : C, 66.65; H, 6.48; N, 8.18\%. Found: C, 66.95; H, 6.56; N, 7.89\%. IR 3432, 2935, 1651, $1593,1512,1467,1430,1127,1026,826 \mathrm{~cm}^{-1} .{ }^{1} \mathrm{H}$ NMR $\left(\mathrm{DMSO}-d_{6}\right) \delta 1.89\left(\mathrm{~m}, 2 \mathrm{H}, \mathrm{CH}_{2}\right), 3.52(\mathrm{t}, \mathrm{J}=6.4 \mathrm{~Hz}, 4 \mathrm{H}$, $\left.2 \mathrm{XCH}_{2}\right), 3.56\left(\mathrm{~s}, 6 \mathrm{H}, 2 \mathrm{X}-\mathrm{OCH}_{3}\right), 4.50$ (bs, 2H, 2xOH), 6.79 (d, J = 8.4 Hz, 2H, Ar), 7.08 (d, J = 8.4 Hz, 2H, Ar), 7.31 (s, $2 \mathrm{H}, \mathrm{Ar}), 8.15(\mathrm{~s}, 2 \mathrm{H}, \mathrm{CH}=\mathrm{N}) .{ }^{13} \mathrm{C}$ NMR (DMSO- $\left.d_{6}\right) \delta 32.6$, $55.8,58.6,110.2,115.6,123.1,128.1,148.3,149.9,160.9$.

2.5. General Procedure for Synthesis of Metal Chelates 4cM. Polymer $4 \mathrm{c}(0.382 \mathrm{~g}, 1.0 \mathrm{mmol}$ of repeating unit) was dissolved in minimum volume of a $1: 1$ mixture of methanol and $0.1 \mathrm{M}$ aqueous sodium hydroxide, and a solution of metal chloride $(0.5 \mathrm{mmol})$ in $5 \mathrm{~mL}$ of water was added. The resulting solution was heated at $60^{\circ} \mathrm{C}$ for $3 \mathrm{~h}$ and cooled, and precipitate formed was isolated by centrifugation $(1700 \times \mathrm{g}$, $6 \mathrm{~min}$ ) and dried under vacuum at $50^{\circ} \mathrm{C}$ to give metalchelated divanillin Schiff base polymers: $4 c-C u(I I)$ brown powder, $91 \%$ yield: $\mathbf{4 c - F e ( I I )}$ yellowish-brown powder $92 \%$ yield: 4c-Co(II) dark brown powder 95\% yield. FT-IR spectra data of these metal chelated polymers are shown in Table 3.

\section{Results and Discussion}

3.1. Synthesis and Characterization of $N, N^{\prime}$-bis(vanillidene)1,3-propanediamine (5). Model compound $N, N^{\prime}$-bis (vanillidene)-1,3-propanediamine (5) (Figure 2) was prepared to collect spectroscopic data that can be used as tools in the characterization of polymeric Schiff bases of divanillin. The ${ }^{1} \mathrm{H}$ NMR of 5 showed imine hydrogens as a singlet at $8.15 \mathrm{ppm}$, and the imine carbons were observed in ${ }^{13} \mathrm{C} \mathrm{NMR}$ at $160.9 \mathrm{ppm}$. The $\mathrm{C}=\mathrm{N}$ imine absorption in the IR spectrum was observed as a strong peak at $1651 \mathrm{~cm}^{-1}$.

3.2. Synthesis of Divanillin Schiff Base Polymers (4ac). Condensation divanillin (2) with three diamines (3ac) produced three divanillin Schiff base polymers (4ac) as shown in Figure 1. These brightly yellow polymers are insoluble in water, and all common organic solvents, slightly soluble in warm DMSO and DMF, however, readily dissolve in dilute aqueous $\mathrm{NaOH} .{ }^{1} \mathrm{H},{ }^{13} \mathrm{C} \mathrm{NMR}$ data, thermogravimetric analysis data, and FT-IR data of polymers 4a-c are shown in Tables 1, 2, and 3, respectively. All three polymers showed strong $-\mathrm{C}=\mathrm{N}-$ absorptions in the IR spectra in the $1654-1656 \mathrm{~cm}^{-1}$ range. This value is comparable to the $1651 \mathrm{~cm}^{-1}-\mathrm{C}=\mathrm{N}-$ absorption in the model compound $N, N^{\prime}$-bis(vanillidene)-1,3-propanediamine (5). ${ }^{1} \mathrm{H}$ NMR spectra of polymers $4 \mathbf{a}, \mathbf{b}$, and $\mathbf{c}$ showed imine 
TABle 3: FT-IR data of divanillin Schiff base polymers (4a-c), metal chelated divanillin Schiff base polymers $4 \mathbf{c}-\mathbf{C u}(\mathrm{II})$, $4 \mathbf{c}-\mathrm{Fe}(\mathrm{II})$, and $4 \mathbf{c}-$ Co(II).

\begin{tabular}{|c|c|c|c|c|c|c|}
\hline Polymer & $\begin{array}{l}-\mathrm{O}-\mathrm{H} \\
\left(\mathrm{cm}^{-1}\right)\end{array}$ & $\begin{array}{c}-\mathrm{CH}=\mathrm{N}- \\
\left(\mathrm{cm}^{-1}\right)\end{array}$ & $\begin{array}{c}-\mathrm{C}=\mathrm{C}-(\mathrm{Ar}) \\
\left(\mathrm{cm}^{-1}\right)\end{array}$ & $\begin{array}{l}-\mathrm{C}-\mathrm{O} \\
\left(\mathrm{cm}^{-1}\right) \\
\end{array}$ & $\begin{array}{c}\text { Metal-O } \\
\left(\mathrm{cm}^{-1}\right)\end{array}$ & $\begin{array}{c}\text { Metal-N } \\
\left(\mathrm{cm}^{-1}\right)\end{array}$ \\
\hline $4 a$ & $3402 \mathrm{~b}$ & $1656 \mathrm{~s}$ & $1594 \mathrm{~s}, 1463 \mathrm{~s}$ & $1274 \mathrm{~s}$ & - & - \\
\hline $4 b$ & $3397 \mathrm{~b}$ & $1654 \mathrm{~s}$ & $1591 \mathrm{~s}, 1462 \mathrm{~s}$ & $1270 \mathrm{~s}$ & - & - \\
\hline $4 c$ & $3409 \mathrm{~b}$ & $1656 \mathrm{~s}$ & $1593 \mathrm{~s}, 1462 \mathrm{~s}$ & $1276 \mathrm{~s}$ & - & - \\
\hline $4 \mathrm{c}-\mathrm{Cu}(\mathrm{II})$ & $3408 \mathrm{~b}$ & $1643 \mathrm{~s}$ & $1586 \mathrm{~s}, 1463 \mathrm{~s}$ & $1268 \mathrm{~s}$ & $611 \mathrm{~m}$ & $704 \mathrm{~m}$ \\
\hline $4 c-F e(I I)$ & $3389 \mathrm{~b}$ & $1645 \mathrm{~s}$ & $1589 \mathrm{~s}, 1458 \mathrm{~s}$ & $1265 \mathrm{~s}$ & $588 \mathrm{~m}$ & $660 \mathrm{~m}$ \\
\hline $4 c-C o(I I)$ & $3382 \mathrm{~b}$ & $1642 \mathrm{~s}$ & $1590 \mathrm{~s}, 1459 \mathrm{~s}$ & $1266 \mathrm{~s}$ & $601 \mathrm{~m}$ & $701 \mathrm{~m}$ \\
\hline
\end{tabular}

b: broad, s: sharp, m: medium.

hydrogen peaks at $8.14,8.15$, and $8.20 \mathrm{ppm}$, respectively, whereas similar $-\mathrm{HC}=\mathrm{N}-$ peak of the model compound 5 was observed at $8.15 \mathrm{ppm}$. The imine carbon resonances of polymers $4 \mathbf{a}, \mathbf{b}$, and $\mathbf{c}$ were observed at 164.2, 164.5, and $162.0 \mathrm{ppm}$ (Table 1), and corresponding signal in the model compound 5 was seen at 160.9 ppm, confirming the Schiff base structure in these polymers. Thermogravimetric analysis showed (Table 2) that all three polymers $\mathbf{4 a - c}$ are stable up to about $250^{\circ} \mathrm{C}$.

3.3. Synthesis of Metal Chelated Polymers 4c-M(II). The metal ion chelating ability of the representative polymer prepared from 1,6-diaminohexane was tested by treatment of the sodium salt of the polymer with chloride salts of $\mathrm{Cu}(\mathrm{II}), \mathrm{Fe}(\mathrm{II})$, and $\mathrm{Co}(\mathrm{II})$ in aqueous methanol medium. The resulting metal-chelated polymers were yellow-brown powders that are completely insoluble in water and all common organic solvents. The chelation of metal is evident from characteristic shift of $-\mathrm{CH}=\mathrm{N}-$ IR absorption band to lower wave numbers by $11-14 \mathrm{~cm}^{-1}$ and $\mathrm{C}-\mathrm{O}$ band by $8-11 \mathrm{~cm}^{-1}$. Similar shifts are known in the complexation of metal ions with salen-type ligands as well $[20,25,26]$. Additionally, the appearance of two moderate peaks around 600 and $700 \mathrm{~cm}^{-1}$ due to metal-O and metal-N absorptions confirms the chelation of metal to imine nitrogen and phenolic oxygen of the polymer. Based on the shifts in IR absorptions and similar Schiff base organometallic polymers reported in the literature $[20,26]$, general structure $4 \mathbf{c}-\mathbf{M}(\mathrm{II})$ shown in Figure 3 is proposed for these novel metal chelated polymers.

\section{Conclusion}

We have shown that condensation of renewable resources based monomer divanillin with alkyl diamines gives low molecular weight Schiff base polymers in excellent yields. The Schiff base as well as phenolic binding sites in the polymer are shown to complex with $\mathbf{C u}(\mathbf{I I}), \mathbf{F e}(\mathrm{II})$, and Co(II) metal ions. This class of vanillin-based polymers can be used to chelate and remove metal ions from aqueous solutions.

\section{Acknowledgments}

The authors would like to thank the American Chemical Society-PRF Grant UR1-49436, NSF Grant CBET-0929970, and USDA Grant CBG-2010-38821-21569 for financial support. The NMR spectrometer used in this study was obtained through a NSF MRI Grant CHE-0421290.

\section{References}

[1] V. Mittal, Renewable Polymers, Scrivener Publishing, Salem, Mass, USA, 2012.

[2] L. Yu, K. Dean, and L. Li, "Polymer blends and composites from renewable resources," Progress in Polymer Science, vol. 31, no. 6, pp. 576-602, 2006.

[3] L. Montero De Espinosa and M. A. R. Meier, "Plant oils: the perfect renewable resource for polymer science?!" European Polymer Journal, vol. 47, no. 5, pp. 837-852, 2011.

[4] V. Sharma and P. P. Kundu, "Addition polymers from natural oils-a review," Progress in Polymer Science, vol. 31, no. 11, pp. 983-1008, 2006.

[5] S. S. Umare, A. S. Chandure, and R. A. Pandey, "Synthesis, characterization and biodegradable studies of 1,3-propanediol based polyesters," Polymer Degradation and Stability, vol. 92, no. 3, pp. 464-479, 2007.

[6] A. A. Patel and S. R. Patel, "Synthesis and characterization of furfural-acetone polymers," European Polymer Journal, vol. 19, no. 3, pp. 231-234, 1983.

[7] P. B. Arora, H. S. Patel, and S. R. Patel, "Resacetophenonefurfural polymers," European Polymer Journal, vol. 23, no. 4, pp. 307-309, 1987.

[8] A. Gandini, A. J. D. Silvestre, C. P. Neto, A. F. Sousa, and M. Gomes, "The furan counterpart of polyethylene terephthalate: an alternative material based on renewable resources," Journal of Polymer Science A, vol. 47, no. 1, pp. 295-298, 2009.

[9] A. Gandini, "Furans as offspring of sugars and polysaccharides and progenitors of a family of remarkable polymers: a review of recent progress," Polymer Chemistry, vol. 1, no. 3, pp. 245251,2010

[10] A. Gandini and M. N. Belgacem, "Furan derivatives and furan chemistry at the service of macromolecular materials," in Monomers, Polymers and Composites from Renewable Resources, B. M. Naceur and A. Gandini, Eds., Elsevier, Amsterdam, The Netherland, 2008.

[11] H. Liu and J. Zhang, "Research progress in toughening modification of poly(lactic acid)," Journal of Polymer Science $B$, vol. 49, no. 15, pp. 1051-1083, 2011. 
[12] J. J. Bozell, L. Moens, D. C. Elliott et al., "Production of levulinic acid and use as a platform chemical for derived products," Resources, Conservation and Recycling, vol. 28, no. 3-4, pp. 227-239, 2000.

[13] A. S. Amarasekara and S. Hawkins, "Synthesis of levulinic acid-glycerol ketal-ester oligomers and structural characterization using NMR spectroscopy," European Polymer Journal, vol. 47, no. 12, pp. 451-2457, 2011.

[14] J. D. P. Araújo, C. A. Grande, and A. E. Rodrigues, "Vanillin production from lignin oxidation in a batch reactor," Chemical Engineering Research and Design, vol. 88, no. 8, pp. 1024-1032, 2010.

[15] T. Voitl and P. R. Von Rohr, "Demonstration of a process for the conversion of kraft lignin into vanillin and methyl vanillate by acidic oxidation in aqueous methanol," Industrial and Engineering Chemistry Research, vol. 49, no. 2, pp. 520525, 2010.

[16] V. E. Tarabanko, D. V. Petukhov, and G. E. Selyutin, "New mechanism for the catalytic oxidation of lignin to vanillin," Kinetics and Catalysis, vol. 45, no. 4, pp. 569-577, 2004.

[17] H. Priefert, J. Rabenhorst, and A. Steinbüchel, "Biotechnological production of vanillin," Applied Microbiology and Biotechnology, vol. 56, no. 3-4, pp. 296-314, 2001.

[18] A. Gosling, S. J. Fowler, M. S. O'Shea, M. Straffon, G. Dumsday, and M. Zachariou, "Metabolic production of a novel polymer feedstock, 3-carboxy muconate, from vanillin," Applied Microbiology and Biotechnology, vol. 90, no. 1, pp. 107116, 2011.

[19] L. Mialon, A. G. Pemba, and S. A. Miller, "Biorenewable polyethylene terephthalate mimics derived from lignin and acetic acid," Green Chemistry, vol. 12, no. 10, pp. 1704-1706, 2010.

[20] I. Kaya, A. Bilici, and M. Gül, "Schiff base substitute polyphenol and its metal complexes derived from $o$-vanillin with 2,3diaminopyridine: synthesis, characterization, thermal, and conductivity properties," Polymers for Advanced Technologies, vol. 19, no. 9, pp. 1154-1163, 2008.

[21] H. Yamamoto, T. Hoshino, and T. Uchiyama, "Convenient preparation and quantification of 5,5'-diferulic acid," Bioscience, Biotechnology and Biochemistry, vol. 63, no. 2, pp. 390394, 1999.

[22] R. T. Nishimura, C. H. Giammanco, and D. A. Vosburg, "Green, enzymatic syntheses of divanillin and diapocynin for the organic, biochemistry, or advanced general chemistry laboratory," Journal of Chemical Education, vol. 87, no. 5, pp. 526-527, 2010.

[23] A. S. Amarasekara, B. Wiredu, and A. Razzaq, "Vanillin based polymers: I. An electrochemical route to polyvanillin," Green Chemistry, vol. 14, no. 9, pp. 2395-2397, 2012.

[24] A. S. Amarasekara, D. Green, and L. D. Williams, "Renewable resources based polymers: synthesis and characterization of 2,5-diformylfuran-urea resin," European Polymer Journal, vol. 45, no. 2, pp. 595-598, 2009.

[25] A. S. Amarasekara, A. R. Oki, I. McNeal, and U. Uzoezie, "One-pot synthesis of cobalt-salen catalyst immobilized in silica by sol-gel process and applications in selective oxidations of alkanes and alkenes," Catalysis Communications, vol. 8, no. 7, pp. 1132-1136, 2007.

[26] M. Tunçel, A. Özbülbül, and S. Serin, "Synthesis and characterization of thermally stable Schiff base polymers and their copper(II), cobalt(II) and nickel(II) complexes," Reactive and Functional Polymers, vol. 68, no. 1, pp. 292-306, 2008. 

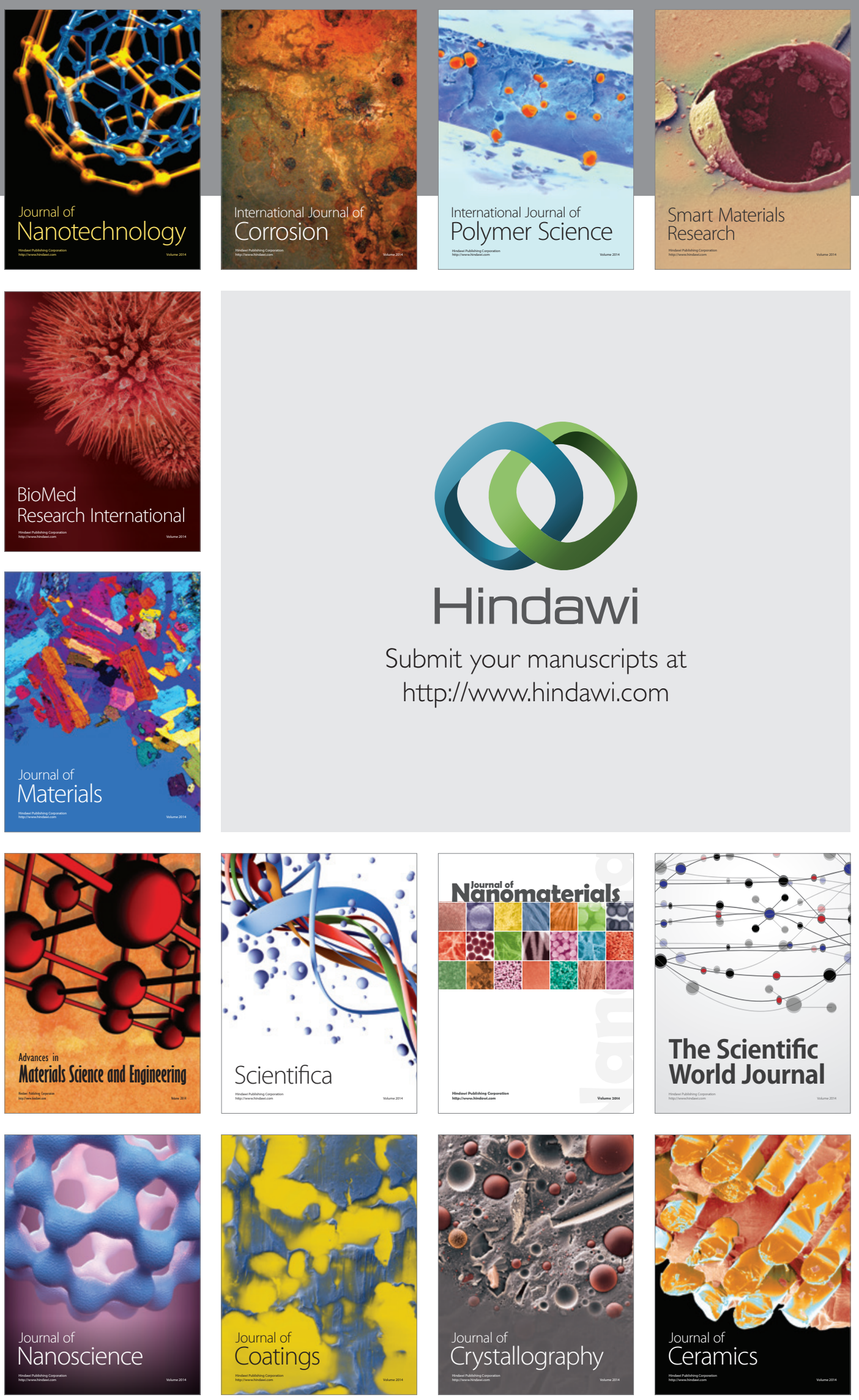

The Scientific World Journal

Submit your manuscripts at

http://www.hindawi.com

\section{World Journal}

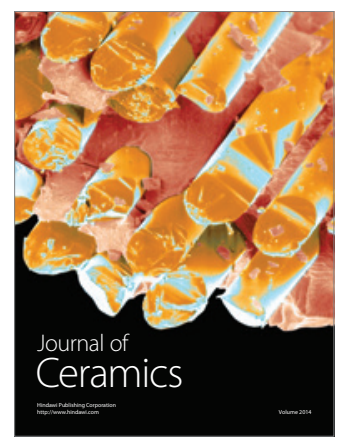

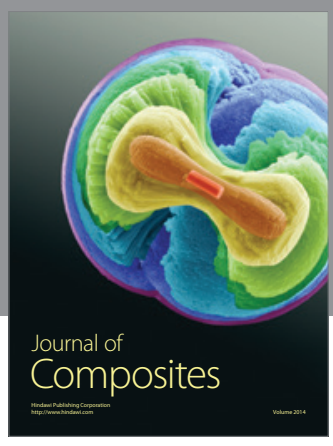
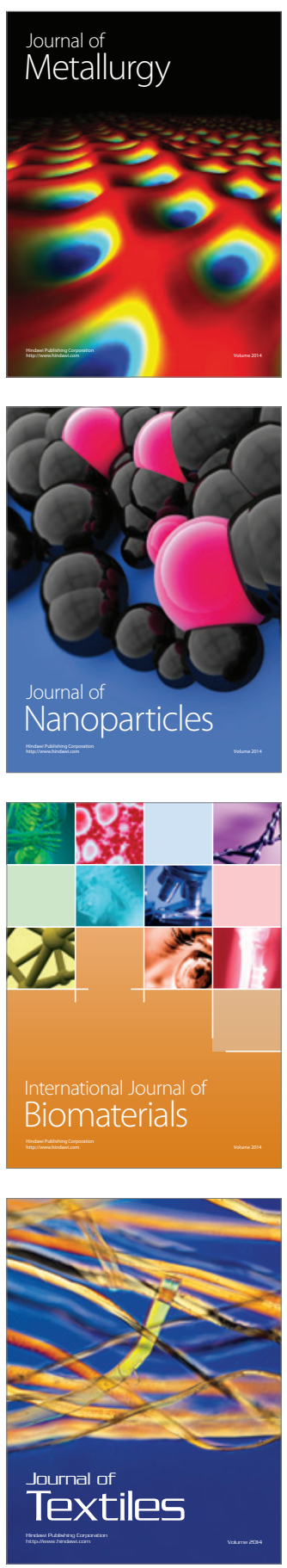